\title{
Identification of Contamination Sources and TDS Concentration in Groundwater of Second Biggest City of Pakistan
}

\author{
M. M. Akhtar and Zhonghua Tang
}

\begin{abstract}
The importance of fresh water for human health has no doubt, even for other uses its quality must be contain standard composition. In developing countries groundwater contamination come from various sources which contains very complicated toxics elements such as landfills, waste water drains, river, industrial and agriculture sectors. Due to lack of management resources, policies and enforcement of environmental laws properly are making groundwater system unsuitable for general public. Lahore, second largest city of Pakistan has been facing similar issues. Current study is to investigate present groundwater contamination sources and describes TDS concentration in various parts of study area. Landfill leachate, drain water, River water and groundwater chemical analysis data is used to indentify TDS potential level in groundwater system.

$36 \%$ groundwater samples have high concentration level then Pakistan Quality Control Authority (PSQCA), while 1.5\% is exceeded from WHO standards for drinking water. TDS higher level is alarming for consumers and with time its potential will be higher. According to 2010 groundwater chemical analysis data most areas have suitable zones for drinking purpose; however, there is high risk of continuous contamination. Finally, this study identifies highly contaminated groundwater and makes convenient to find out actual pollutants. Therefore, practical strategies are needed to protect aquifer.
\end{abstract}

Index Terms-Groundwater contamination, landfill, lahore, TDS.

\section{INTRODUCTION}

It is difficult to make it balance about natural resources consuming and availability, due to ever sprawling cities and there increasing demand. The pollutants infiltrations from various resources (river, landfill sites, drains, agriculture effluents and municipal sewerage) are making portable water deteriorate[1]. Dumping sites are expected locations for contamination production and infiltration, more over it need to assess the impacts on our ecosystem and general public [2] Urban pollutants origins are different from rural areas and contains high level of toxic chemicals which come from sewage, dumping sites, industries and cultivation activities [3]. Generally, Polar and non-polar complex chemicals compounds are infiltrating from landfill leachate, which contains thousands of types of elements [4]. While Organic, inorganic, heavy metals and toxic chemicals concentration

Manuscript received February 7, 2013; revised March 30, 2013.

The authors are with School of Environmental Studies, China University of Geosciences, 388 Lumo Road, Wuhan, Hubei, China. (Email:malikma_2012@yahoo.com,zhhtang@cug.edu.cn). level has been continuously increasing in various areas of world [5]. Urban contaminated soil is affecting number of ways directly and indirectly to human health [6]

Groundwater Over-exploitation combined with low recharge rat, its result in shape of more pollutants infiltration and rapid deterioration of water quality. A number of factors have led to alter in groundwater composition over all the world, but most significant affecting from human activities [7]. Emília Silva explored during his study that groundwater exposure to pesticides is determined by environmental or agricultural, geology, as precipitation, crops, soil and irrigation practices. Deterioration of groundwater supplies related to human activities may result from poorly designed landfills, open drains, and a lack to sewage and waste water treatment. These problems are particularly acute in developing countries where poor water management systems are exacerbating the problems.

Present study is involved analysis of physico-chemical data from groundwater samples collected in Lahore from selected points in order to assess suitability of drinking water. Also, contamination sources analysis data presented for understanding real condition of study area. However during the current study two different drinking water standards were applied for comparison, those of WHO and PSQCA, to assess the groundwater in Lahore for its suitability for human consumption as regard to TDS. The study identified the poor water quality, which can be used to identify sources of pollutants, thus allowing municipal officials to take precautionary measures to protect the aquifer.

\section{Study Area And SAmpling PoInTs}

Lahore second biggest city of Pakistan is a rapidly growing without considering environmental affects lying between latitudes $31^{\circ} 20^{\prime}$ and $31^{\circ} 50^{\prime} \mathrm{N}$ and longitudes $74^{\circ} 05^{\prime}$ and $74^{\circ} 37^{\prime} \mathrm{E}$ in the province of Punjab. The study area is located on the east bank of the famous Ravi River. Its boundaries extend from the Hudiara Drain in the south, across the Ravi River and finally eastward to the border with India [8] (Fig. 1). Lahore is located on a low alluvial plain, an area undergoing rapid development with little concern for the geo-environmental consequences. A rapid growing population, increasing groundwater depletion, pollution and scarcity are considered the biggest challenges for this groundwater-dependent city. Both the temperature and rainfall vary greatly from season to season with a mean temperature that ranges from $34^{\circ} \mathrm{C}$ in June to $12^{\circ} \mathrm{C}$ in January and an average rainfall of $575 \mathrm{~mm}$ per year, which can vary 
from 300 to $1200 \mathrm{~mm}$. The evapotranspiration is about 1750 $\mathrm{mm}$ per year, which is the principal reason why extensive irrigation is needed for agricultural purposes (NESPAK 1993: Ref [9]).

Modern soils in the area consist of silt, clay, loamy clay and sand, however, loamy clay gradually increases with distance from the Ravi River [10]. The aquifer underlying the Lahore area is composed of unconsolidated alluvial sediments; composed of varying proportions of silt, sand and clay.

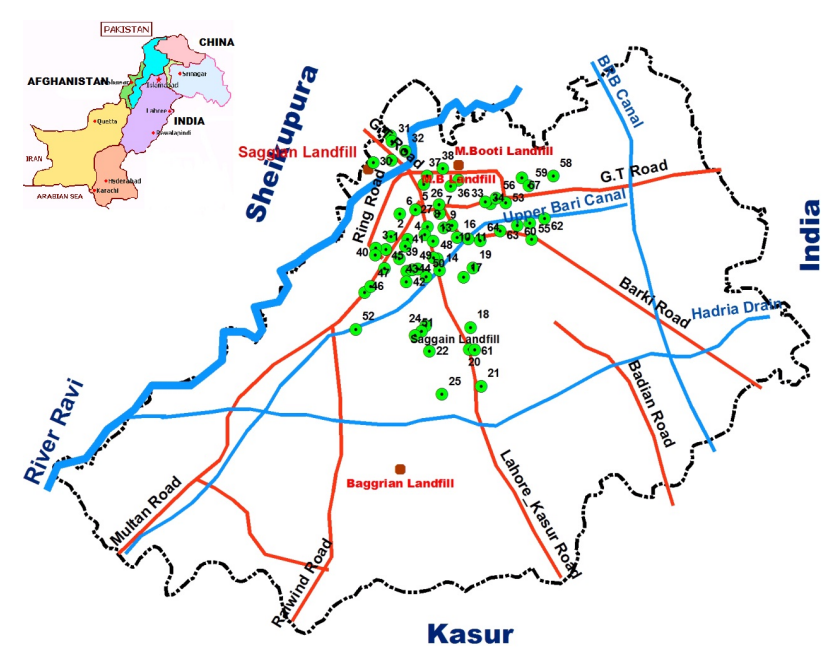

Fig. 1. Study Area with groundwater sampling points

\section{POllutants SOURCES}

The major contributors to groundwater contamination are disposal of solid waste and sewage, agricultural activities, urban runoff and polluted surface water [9].the Ravi River presently receives $47 \%$ of all municipal and industrial pollution load discharged into all the rivers of Pakistan (Sami F. 2001. Ref: [10]). River Ravi water chemical analysis data shows that contamination level is high and source for groundwater deterioration (Table I). TDS level in River Ravi water is very high at Syphon point, even it will be increase near Shahdara.

\begin{tabular}{lc} 
TABLE I: RIVER RAVI WATER ANALYSIS REPORT AT SYPHON POINT (2010) \\
\hline PARAMETERS & RESULTS (mg/l) \\
\hline $\mathrm{pH}$ & 8.8 \\
$\mathrm{TDS}$ & 952 \\
$\mathrm{Ca}$ & 23 \\
$\mathrm{Mg}$ & 3.7 \\
Chloride $\left(\mathrm{Cl}^{-1}\right)$ & 72 \\
Sulphate $\left(\mathrm{SO}_{4}\right)^{-2}$ & 183 \\
Total hardness & 21 \\
\hline
\end{tabular}

\section{Source: Author}

The Hudiara drain receives effluents from India side with high concentrations of pollutants and then collects additional contaminated waste water from Pakistan before flowing into the Ravi River without any waste water treatment. The waste water from various sources contains organic, inorganic, industrial, municipal and animal waste, as well as fertilizers and insecticides, which seep through the soil and significantly degrade the soil and groundwater quality.
Punjab Environmental department conducted a study on drain waste water, which is percolated throughout its flow and on the fall into River Ravi. Table II shows high TDS concentration in drain waste water.

TABLE II: WASTEWATER ANALYSIS REPORT OF THE MEHMOOD BOOTI DRAIN, LAHORE BEFORE MIXING INTO RIVER RAVI (SOURCE: PUNJAB ENVIRONMENTAL DEPARTMENT LAHORE [PERSONALLY COLLECTED])

\begin{tabular}{lcc}
\hline PARAMETERS & N.E.Q.S. (mg/l) & RESULTS $(\mathrm{mg} / \mathrm{l})$ \\
\hline BOD & 80 & 1210 \\
COD & 150 & 4160 \\
TDS & 3500 & 760 \\
TSS & 200 & 360 \\
Chloride $\left(\mathrm{Cl}^{-1}\right)$ & 1000 & 100 \\
Sulphate $\left(\mathrm{SO}_{4}\right)^{-2}$ & 600 & 158 \\
Sulfide & 1 & 8 \\
Fluoride $\left(\mathrm{As} \mathrm{F}^{\prime}\right)$ & 10 & 0.57 \\
Cyanide $(\mathrm{As} \mathrm{CN})$ & 2 & \\
Manganese & 1.5 & 0.101 \\
Copper & 1 & 0.06 \\
Cadmium & 0.1 & 0.031 \\
Chromium & 1 & 0.01 \\
Zinc & 5 & 0.047 \\
Iron & 8 & 1.35 \\
Nickel & 1 & 0.012 \\
\hline
\end{tabular}

Landfills play a vital role in a large city like Lahore. It can be understand that without functional landfill areas big cities become garbage places and it will be a constant source of risk for general public health. There are three active waste dumps present around Lahore, which are unplanned and contributing a significant amounts of pollutants into groundwater system. At least three-fourths of the total waste generated collected in Lahore every day (3800 tons) is dumped at these sites without proper treatment. Fig. 2 shows solid waste composition because it's very important to understand its leachate generation.

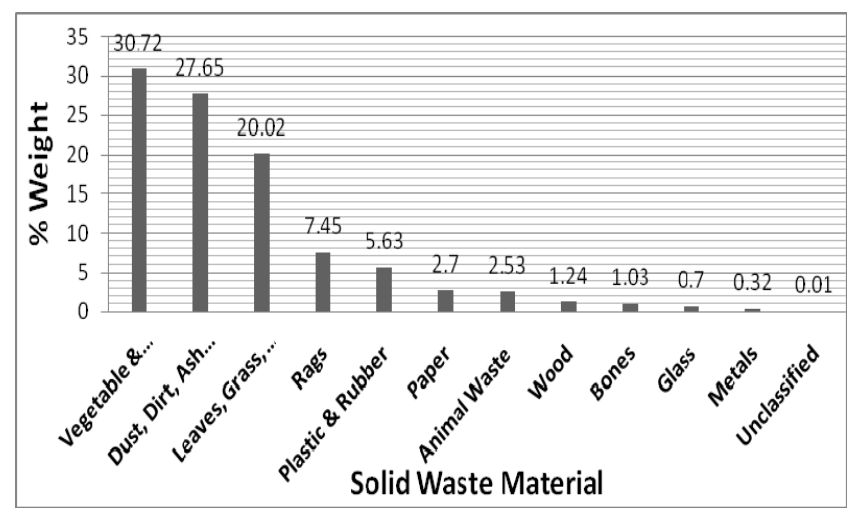

Fig. 2. Composition of dumping material at landfills in Study area (based on Haydar et al., 2012 [11] and LWMC Department)

Several studies examining leachate samples from landfill sites (Table III) showed that most of the parameters such as colour, conductivity, TSS, TDS, BOD, COD, NH3-N, PO4-P, SO4 -2, Cl-1and Fe were at high levels. Both landfill sites are unplanned and construction patron is not favourable to collect toxic leachate. Therefore, it is expected that whole leachate infiltrated towards groundwater system. Various studies have been conducted on dumping sites and its 
leachate effects. Mehmood Booti Landfill site is oldest one and both sites are located on river flood plain in Lahore city.

Landfill leachate data is presented, which explores that leachate contains high level of various pollutants.

TABLE III: LEACHATE ANALYSIS FROM TwO LANDFILLS FROM LAHORE CITY

\begin{tabular}{lrlr}
\hline Saggian Landfill & & Mehmood Booti Landfill & \\
\hline Parameter & Value & Parameter & Value \\
$\mathrm{pH}$ & 6.8 & $\mathrm{pH}$ & 6 \\
$\mathrm{COD}(\mathrm{mg} / \mathrm{l})$ & 2563 & $\mathrm{COD}(\mathrm{mg} / \mathrm{l})$ & 18,000 \\
$\mathrm{BOD}(\mathrm{mg} / \mathrm{l})$ & 442 & BOD(mg/l) & 10,000 \\
$\mathrm{TDS}(\mathrm{mg} / \mathrm{l})$ & 3717 & TDS(mg/l) & 3500 \\
TSS(mg/l) & 161.7 & TSS(mg/l) & 500 \\
Conductivity(mg/l) & 5829 & Conductivity(mg/l) & 7154 \\
Surfactant(mg/l) & 1.58 & Sulfate(mg/l) & 300 \\
Pb (mg/l) & 0.6 & Total Nitrogen(mg/l) & 400 \\
Cu(mg/l) & 2.7 & Chlorides(mg/l) & 500 \\
As(mg/l) & 0.2 & T. Phosphorous(mg/l) & 30 \\
Fe(mg/l) & 9.8 & Total Iron(mg/l) & 60 \\
\hline Source:(Khurshed et.al.,2010)[11] & Source: (Tchobanoglous et. al.,
\end{tabular}

\section{Methodology}

The thematic map contains comprehensive information about the city boundaries, road network, water fields (sweet water zones), landfills and samples location within Lahore (Fig. 1). The groundwater samples were all collected from production wells, and water quality was assessed based on the available physico-chemical data. The chemical analysis data were used for water from 64 pumping wells in April 2010.

Groundwater sample bottles $(500 \mathrm{ml}$ and $100 \mathrm{ml}$ capacity) were sterilized at $150{ }^{\circ} \mathrm{C}$ and apparatus used in this study was washed with chromic acid and dried in an oven. To prepare reagents double distilled water was used. Analytical grade chemicals and reagents were used in this study without further purification. Inorganic chemicals were kept in the oven at the temperature of $120^{\circ} \mathrm{C}$ to remove moister. For bacteriological analysis, sampling taps were cleaned with ethyl spirit followed by a flame to avoid contamination from external environment. Tests TDS was performed within one hour of collection.

Relation among various pollutants sources and aquifer system will be develop by considering drain, landfill leachate and river pollution potential level. Water quality with respect to TDS concentration level will be investigated with groundwater chemical analysis results.

\section{RESUlts}

In current study, an only single but very important pollutant is selected to present and discuss. The TDS include all mineral constituents and other solids dissolved the water. The TDS in water is a general indicator of the overall suitability of water for many types of uses. High values of TDS influence the taste, hardness, and corrosive property of the water [13], [14]. Water with more than $1000 \mathrm{mg} / \mathrm{L}$ of dissolved solids usually has a disagreeable taste and may have laxative effect or makes the water unsuitable in other respects. The TDS concentration in natural water is usually less than $500 \mathrm{mg} / \mathrm{L}$, and water with more than $500 \mathrm{mg} / \mathrm{L}$ is undesirable for drinking and many industrial uses. Water with TDS less than $300 \mathrm{mg} / \mathrm{L}$ is desirable for dyeing of cloths and the manufacture of plastics, pulp paper, etc [15]. Irrigation areas used groundwater are encumbered by the potential concentration of sodium and TDS [16]. Subba and Sohani reported that high TDS concentrations are due to the presence of bicarbonates, carbonates, sulphates, chlorides and calcium, which may originate from natural sources, sewage, urban runoff, and industrial wastewater[17], [18]. They can also be derived from chemicals used in the water treatment process and from pipes or other hardware used in the plumbing [19]. The TDS can be removed by reverse osmosis, electrodialysis, exchange and solar distillation.

To determine the suitability of groundwater for any purpose, it is important to classify it according to its hydro-chemical properties based on TDS values, which are represented in Table IV. Fig. 3, depicts TDS contamination concentration level in 64 collected samples according to WHO and PSQCA criteria. These results show that TDS level is higher than described standards in some parts of study area and need to treatment.

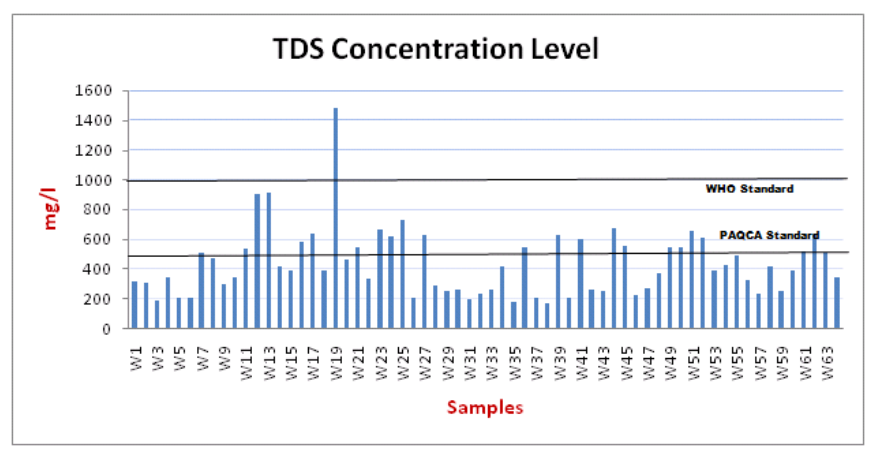

Fig. 3. TDS concentration level in 64 groundwater samples

It is recommended that waters containing more than 500 $\mathrm{mg} / \mathrm{l}$ of dissolved solids not be used if other less mineralized supplies are available. The maximum contaminant level (MCL) for TDS in drinking water is given as $1000 \mathrm{mg} / \mathrm{L}$ by WHO and $500 \mathrm{mg} / \mathrm{L}$ by PSQCA (Table IV). However, $98.5 \%$ of the analysed water samples were classified as acceptable using WHO standards but only 64. \% qualified using PSQCA standards. The areas of highest TDS are in Ravi Town, Data Town and Gulberg Town. There is a landfill located in Ravi Town and this is the apparent source of the pollutant there. The highest TDS concentrations are near the center of Data Town and in the west part of Gulberg Town. Water taken from areas near the river and the cannels has the lowest TDS. The high concentrations occur in areas of over exploitation and low recharge making it possible for, pollutants to seep in quickly. The main reason is that main city area is mostly constructed and groundwater recharge rate is very low, while over abstraction to fulfill increasing water demand of spreading city. Cone has been developed in groundwater system which is main cause of groundwater movement toward main city area such as Gulberg. Based on our study of TDS, the water samples need treatment before use because most exceed the in PSQCA limits. 
TABLE IV: SUMMERY GROUNDWATER SAMPLES AND STANDARDS

\begin{tabular}{cccc}
\hline Parameter & No. of Samples & WHO Criteria & PAQCA Criteria \\
\hline TDS & 64 & $1000 \mathrm{mg} / 1$ & $500 \mathrm{mg} / 1$ \\
& Range & $1.56 \%$ & $36 \%$ \\
& $173.2-1480.5$ & Over Criteria & Over Criteria \\
\hline Ref: [20], [21] & & &
\end{tabular}

\section{CONCLUSION}

Recently, Lahore is facing a number of groundwater issues, such as water shortages, locally high pollution, and low recharge and over exploitation of the resource. The major sources of pollution in the study area are poor unregulated landfills, contaminated river water and drain systems. All of these problems will only become worse unless steps are taken in the very near future. It is expected that the present study will provide some guideline for the development of a comprehensive water management and land use program. The local authorities have no solid strategy to protect the groundwater system from pollutant, which are continually infiltrating into the aquifer. If the present level of contamination continues, or increases, no potable water will be available in Lahore after few years. The results of the current study should help the general public, local administrators and government agencies to recognize the current and future threats to groundwater quality of Lahore.

A groundwater monitoring system is most important to install at Lahore City. There are some significant recommendations for preventing further groundwater quality deterioration

1) A significant waste water quantity from domestic sewage that enters into the various water bodies located in the city. Effective treatment plants should be installed to treat municipal waste water before through into river or other water bodies. Fractured and old sewage lines must be replace to make it insure fix leaking problem.

2) Landfills must be maintained properly and generated leachate collection mechanism must be established, so that leachate infiltration can be stop into aquifer system. Identify groundwater recharge locations and structures, and ensure that these are protected from surface pollution. Agricultural activities, particularly those using large quantities of fertilizer and pesticide, must be excluded from the recharge sites.

3) Enforce existing environmental protection laws and develop additional rules and regulations as necessary. Violators must be dealt with appropriately and incentive policies must be developed to ensure compliance with all environmental rules and regulations.

4) Environmental and water departments should introduce a groundwater monitoring system, so continuously monitor groundwater levels and quality so that problems can be recognized and dealt quickly. It will also help out to resolve within limited time.

5) Most important step, which take immediate to inform and educate the public and related governing officials about the growing groundwater problems and total costs for preserving the water supply. The relevant municipal and provincial departments should introduce desk to share information and with combine effort try to protect groundwater resource for future.

\section{ACKNOWLEDGMENT}

Authors would like to thank Water and sanitation Agency (WASA) and Punjab Environmental Department Lahore; for providing the research data. Also we would like to thank Professor Paul Robinson for his great help to improve the English language and his advices about organizing the paper.

\section{REFERENCES}

[1] N. Milenkovic, M. Damjanovic, and M. Ristic, "Study of heavy metal pollution in sediments from the iron gate (danuae river), serbia and montenegro," Polish Journal of Environmental Studies, vol. 14, pp.781-787, June 2005.

[2] S. Jit, "Evaluation of hexachlorocyclohexane contamination from the last lindane production plant operating in India," Environmental Science and Pollution Research, vol. 18, pp. 586-597, April 2010.

[3] A. Nestler, "Isotopes for improved management of nitrate pollution in aqueous resources: review of surface water field studies," Environmental Science and Pollution Research, vol. 18, pp. 519-533, January 2011.

[4] E. Bacci, A. Franchi, L. Bensi, and C. Gaggi, "Pesticides and groundwater quality protection," Environmental Science and Pollution Research, vol. 1, pp. 94-97, 1994.

[5] E. Helios-Rybicka, "Distribution of pollutants in the Odra river system. Part I. General description of the International Odra Project (IOP)," Polish Journal of Environmental Studies, vol. 11, pp. 649-654, July 2002.

[6] G. Guo, F. Wu, F. Xie and R. Zhang, "Spatial distribution and pollution assessment of heavy metals in urban soils from southwest China," Journal of Environmental Sciences, vol. 24, pp. 410-418, March 2012.

[7] Y. Pan, H. Gong, D. ZHou, X. Li, and N. Nakagoshi, "Impact of land use change on groundwater recharge in Guishui River Basin, China," Chinese Geographical Science, vol. 21, pp. 734-743,December 2011.

[8] P. Sergey, "Adsorption of Cadmium onto Hematite: Temperature Dependence," Journal of colloid and interface science, vol. 1, pp. 234, September 2001.

[9] V. T. Patil and P. R. Patil, "Physicochemical Analysis of Selected Groundwater Samples of Amalner Town in Jalgaon District, Maharashtra, India," E-Journal of Chemistry, vol. 7, pp. 111-116, August 2009.

[10] H. Gabriel and H. S. Khan, "Climate Responsive Urban Groundwater Management Options in a Stressed Aquifer System," IAHS-AISH publication, pp. 166-168, 2010.

[11] S. Khan, T. Rana, H. F. Gabriel, and M. K. Ullah, "Hydrogeologic assessment of escalating groundwater exploitation in the Indus Basin, Pakistan," Hydrogeology Journal, vol. 16, pp. 1635-1654, June 2008.

[12] S. Karim, M. N. Chaudhry, K. Ahmed, and A. Batool, "Impacts of Solid Waste Leachate on Groundwater and Surface Water Quality," Journal of the Chemical Society of Pakistan, vol. 32, pp. 606, March 2010 .

[13] S. Haydar, H. Haider, A. J. Bari, and A. Faragh, "Effect of Mehmood Booti Dumping Site in Lahore on Ground Water Quality," Pak. J. Engg. \& Appl. Sci., vol. 10, pp. 51-56, January 2012.

[14] P. Balakrishnan, A. Saleem, N. D. Mallikarjun, "Groundwater quality mapping using geographic information system (GIS): A case study of Gulbarga City, Karnataka, India," African Journal of Environmental Science and Technology, vol. 5, pp. 1069-1084, December 2011.

[15] K. Joseph, "A cleaner production approach for minimisation of total dissolved solids in reactive dyeing effluents" 2005.

[16] C. Durfer, Public water supplies of the 100 largest cities of the United States, 1962, pp.1812. (BOOK)

[17] E. J. K. Singh, A. Gupta, and N. R. Singh, "Groundwater quality in Imphal West district, Manipur, India, with multivariate statistical analysis of data," Environmental Science and Pollution Research, vol. 1,August 2012.

[18] N. S. Rao, "Groundwater quality: focus on fluoride concentration in rural parts of Guntur district Andhra Pradesh, India," Hydrological Sciences-Journal-des Sciences Hydrologique, vol. 48, pp. 835-847, October 2003.

[19] C. K. Jain, A. Bandyopadhyay, and A. Bhadra, “Assessment of ground water quality for drinking purpose, District Nainital, Uttarakhand, India," Environ Monit Assess, vol. 166, pp. 663-676, June 2009. 
[20] PSQCA, "Pakistan standard specification of bottled drinking water (3rd revision)," in Pakistan Standards and Quality Control Authority, M.o.S.a.T., Government of Pakistan, Ed. Islamabad, 2004.

[21] Guidelines for Drinking-Water, vol 92, World Health Organization, Geneva, 1996, pp. 971.

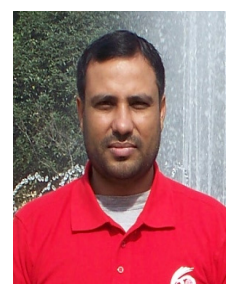

Akhtar, Malik Muhammad is a research scholar, born on April 1975, Sheikhupura (Pakistan). In 2004 received Master degree in Physics from AIOU, Islamabad Pakistan. Currently, he is perusing doctorate degree in Environmental Engineering from China University of Geosciences (Wuhan). Research has been engaged in percolation theory, numerical simulation and groundwater contamination transport modelling. His three SCI publication are under process. Learning softwares and searching new publication is related to environmental.

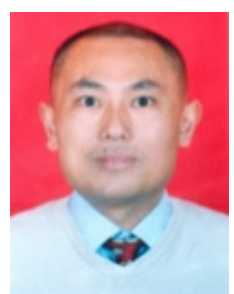

Tang Zhonghua was born in July 1958, in Xiaogan January 1982, he received Bachelor of Science degree in Wuhan College of Geology; July 1989 China University of Geosciences (Wuhan) Engineering from Master; December 1998 China University of Geosciences (Wuhan) obtained his $\mathrm{PhD}$; from January 1982 to participate in Work, has been engaged in percolation theory and numerical simulation work related to teaching and research in 1995 and Professor Approval of doctoral students enrolled in 2003. He has over 70 publications. 